\title{
腹腔鏡下手術後の悪心嘔吐の頻度と術後予防的 メトクロプラミド投与の検討 \\ Postoperative nausea and vomiting after laparoscopic gynecological surgery and effects of prophylactic antiemetic therapy with metoclopramide
}

高知県立中央病院産婦人科

苔口昭次、木森一吉、柳川拓三、長谷川俊水

\section{はじめに}

術後の悪心嘔吐（postoperative nausea and vomiting, 以下PONV）は術後管理時間中の $20-$ $70 \%$ に発現する ${ }^{1,2.3)}$ 。しかし小さな合併症として 麻酔科医や婦人科医の認識はいまだ低いのが現状 である。このPONVは女性に多く、婦人科領域の 手術ではその頻度は高い1)。腹腔鏡下手術におい てもPONVの頻度は、開腹術と変わらないといっ た文献もある ${ }^{4.5)}$ 。腹腔鏡下手術後ではその頻度 は若干低い印象があるが臨床上よく遭遇する。最 近になり5-HT3拮抗薬などの使用による嘔吐抑制 に関する文献が見受けられるが6)、日本では抗癌 剂を併用使用しない限り保険上この5-HT3拮抗薬 を手術当日の使用はできにくい。

当科における腹腔鏡術後の悪心嘔吐の頻度や発 生時期について検討し、PONVを減らすためにメ トクロプラミドの予防的点滴静注投与効果（術後 4-5時間目）を検討した。メトクロプラミドを使 用した理由は、ドロペリドールの静注は低血圧、 過度鎮静、覚醒遅延など副作用のため当院では医 師自身直接投与が原則であり、通常術後指示でき るものとして一般使用薬としてメトクロプラミド

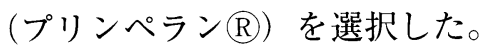

\section{対象と方法}

対象は開腹術（腹式子宮全摘症例）17症例、腹 腔鏡下手術症例 53 例、腹腔鏡下術後メトクロプラ ミド子防的投与例24例である。これらの麻酔方法 は全身麻酔（気管内挿管）でsevoflureneおよび 笑気を使用した。腹腔鏡下手術は全例気腹法であ る。またプロポフォール麻酔例は省いている。ま た術後は鎮痛のため、硬膜外持続注入法を用いて いる。0.25\%bupivacain $50 \mathrm{ml}+$ 塩酸モルヒネ $10 \mathrm{mg}$
を48時間使用している。

症例背景として年齢、BMI (body mass index)、 月経開始日からの日数、手術時間、麻酔時間、 sevoflurene量、 $\mathrm{N}_{2} \mathrm{O}$ 量を調べたがt検定にて sevoflurene量以外には有意差はなかった（表 1 ）。 表 1 症例背景

\begin{tabular}{|c|c|c|c|}
\hline & \multirow{2}{*}{$\begin{array}{c}\text { 開腹TAH症例 } \\
17 \text { 例 }\end{array}$} & \multicolumn{2}{|c|}{ 腹腔鏡下手術例 } \\
\hline & & $\begin{array}{c}\text { 経過観察例 } \\
53 \text { 例 }\end{array}$ & $\begin{array}{c}\text { 予防的投与例 } \\
24 \text { 例 }\end{array}$ \\
\hline 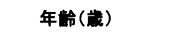 & $45 \pm 13$ & $40 \pm 11$ & $40 \pm 9$ \\
\hline BMI & 21. $9 \pm 2.4$ & 22. $7 \pm 3.3$ & 22. $4 \pm 3.0$ \\
\hline 月経關始日からの日数 & 17. 8 & 18. 1 & 14. 5 \\
\hline 手街時间（min） & $112 \pm 38$ & $110 \pm 48$ & $115 \pm 20$ \\
\hline 麻醉時间 (min) & $163 \pm 44$ & $157 \pm 52$ & $168 \pm 20$ \\
\hline sevoflurene $\mathrm{E}$ (L) & $\stackrel{50 \pm 24}{\llcorner}$ & $\stackrel{74 \pm 39}{\longrightarrow}$ & $\begin{array}{c}79 \pm 22 \\
ل\end{array}$ \\
\hline $\mathrm{N}_{2} \mathrm{O} \sigma \mathbf{t}(\mathrm{L})$ & $305 \pm 123$ & $341 \pm 146$ & $297 \pm 36$ \\
\hline
\end{tabular}

開腹術症例、腹腔鏡下手術（観察群）例、腹腔鏡 下手術後メトクロプラミド予防的投与群それぞれ で、平均年齢45歳、40歳、40歳、月経開始日から の日数は、平均17.8日、18.1日、14.5日、平均手 術時間は112分、110分、115分。平均麻酔時間は 163分、157分、168分であった。平均sevoflurene 使用量は50L、74L、79Lであり、開腹術では少な い使用量であった $(\mathrm{p}<0.05)$ 。平均笑気使用量は 305L、341L、297Lであった。また、ここでいう 開腹症例は、麻酔時間および手術時間に重点を置 いて手術時間が約 2 時間程度かかった症例を対象 とした。

PONVをそれぞれの群について検討するために 悪心嘔吐を点数化して検討した。その点数化は、 悪心なし；0、体動時の悪心；1点、安静時悪心 ; 2点、Retching；3点, Vomiting；4点とした。以 上のようにしたのは術後の悪心嘔吐は連続性のあ るものと考え従来の悪心と嘔吐を個別とした指標 をまとめることが必要であると考えたからであ 
る。嘔吐回数についての定義は、 1 分以内に嘔吐 があった場合には 1 回と判定した（表 2 ）。

表 2 悪心嘔吐の点数化

0 点 悪心 なし

1 点 覀心 動作時に一過性の嘔気あり

2 点 悪心 安静時にも㺿気持続

3 点 空嘔吐 retching

4 点 嘬吐 vomiting

跴吐の回数は 1 分間以上の間隔をおいて発生した 場合には 1 回と数える

PONVの予防としてのメトクロプラミド投与方 法は、腹腔鏡下手術後症例に限り予防的にメトク ロプラミドを術後4-5時間目に点滴静注（生食 $100 \mathrm{ml}+$ 塩酸メトクロプラミド $10 \mathrm{mg}(1 \mathrm{~A}))$ 投与 して後期に起こるPONVを予防できないか検討し た。メトクロラミド大量では雓体外路症状が発症 することもあるが今回使用の $10 \mathrm{mg}$ では副作用発 症はなかった。

\section{結果}

1. 腹腔鏡下手術術後PONVの発症時期（図 1) 頻度と術後時間との関連をあらわすと結果は、 図 1 のようにPONVは術後早期と約 $5-7$ 時間後 に集中する傾向が認められた。

図 1 腹腔鏡下手術後のPONV発症時期

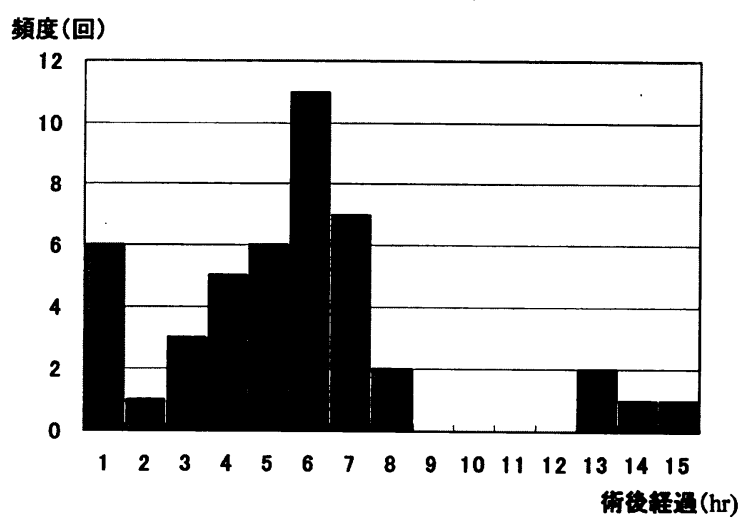

2 . 術後 24 時間以内のPONVの頻度（症例別） (表3)

症例別で一人の患者が 2 回嘔吐をしても 1 とす る検討ではPONVは開腹子宮全摘出例70.6\%に、 腹腔鏡下手術症例で観察群 $54.7 \%$ に,メトクロプラ ミド予防的投与例の $16.7 \%$ に認められた。そのう ち嘔吐（retchingとvomiting）に限るとそれぞれ $52.9 \% 、 35.8 \% 、 12.5 \%$ あった。経過観察例と メトクロプラミド予防的投与例とは $\mathrm{p}<0.05 て ゙$ 有意 にPONVおよび嘔吐（retchingとvomiting）を押
さえることができた。開腹術と腹腔鏡下手術（経

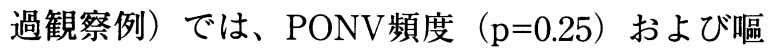
吐（ $\mathrm{p}=0.21 ） に$ 有意差はなかった。検定方法はカ イ二乗検定をおこなった。

表 3 全体のPONV発現頻度（症例別）

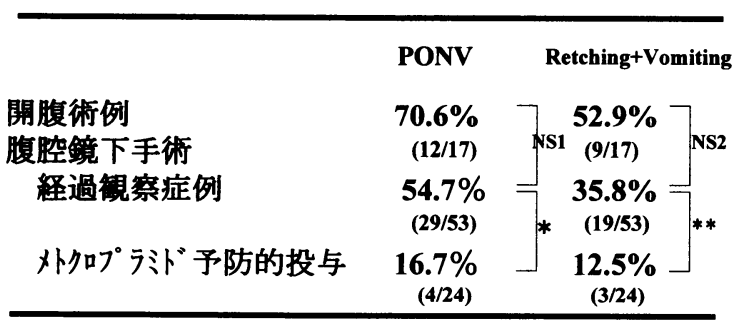

${ }^{\star} p<0.01{ }^{\star *} p<0.05$ NS1 $p=0.25 \quad$ NS2 $P=0.21$

3 . 術後 4 時間以降のPONV発現頻度（症例別） (表 4 )

予防的投与の有効性を調べるために、術後 4 時 間以降にかぎり症例別検討をした。PONVは開腹 子宮全摘出例 $64.7 \%$ に、腹腔鏡下手術症例で観察 群 $49.1 \%$ に,メトクロプラミド予防的投与例の 4.2\%に認められた。そのうち嘔吐 (retchingと vomiting）に限るとそれぞれ $41.2 \% 、 28.3 \%$ 、 $2.1 \%$ であった。経過観察例とメトクロプラミド 予防的投与例とは $\mathrm{p}<0.05$ で有意にPONVを押さえ ることができた。嘔吐に限ると $\mathrm{p}=0.05$ で有意差は なかった。開腹術と腹腔鏡下手術（経過観察例）

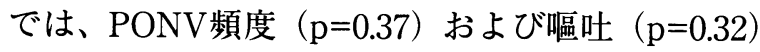
に有意差はなかった。検定方法はカイ二乗検定を おこなった。

表 4 術後 4 時間以降のPONV発現頻度（症例別）

\begin{tabular}{|c|c|c|}
\hline & PONV & Retching+Vomiting \\
\hline 開腹術例 & $\begin{array}{r}64.7 \% \\
(11 / 17)\end{array}$ & $\left.{ }_{\mathrm{NS} 1} \begin{array}{c}41.2 \% \\
(7 / 17)\end{array}\right] \mathrm{NS2}$ \\
\hline 経過钼察症例 & $\begin{array}{c}49.1 \% \\
(26 / 53)\end{array}$ & ]$_{* \quad(15 / 53)}^{28.3 \%}$ \\
\hline メトクロプラミド予防的投与 & $\begin{array}{r}4.2 \% \\
(4 / 24)\end{array}$ & ]$_{(2 / 24)}^{2.1 \%}$ \\
\hline
\end{tabular}

* $p<0.01$ NS1 $p=0.37$ NS2 $p=0.32 \quad$ NS3 $p=0.05$

4.PONV発現回数 (表 5 )

症例別でなく全体としてのPONV回数を隇らす ことができたかの検討をした。PONVは開腹（子 宮全摘出）例では $1.18 \pm 1.24$ 回、腹腔鏡下手術症 例で観察群 $0.86 \pm 1.21$ 回,メトクロプラミド予防的 投与例の $0.52 \pm 1.26$ 回に認められた。そのうち嘔 吐（retchingとvomiting）に限るとそれぞれ $0.71 \pm 0.99$ 回、0.66 \pm 1.12 回、0.32 \pm 0.90 回であっ た。経過観察例とメトクロプラミド予防的投与例 とはPONVについては有意差はなかった 
$(\mathrm{p}=0.24)$ 。また嘔吐に限ると $\mathrm{p}<0.05 て ゙$ 有意差に回 数を押さえることができた。開腹術と腹腔鏡下手 術（経過観察例）では、PONV頻度（ $\mathrm{p}=0.51 ） お ~$ よび嘔吐（ $\mathrm{p}=0.88 ） に$ 有意差はなかった。この検 定は $\mathrm{t}$ 検定をおこなった。

表 5 PONV発現回数

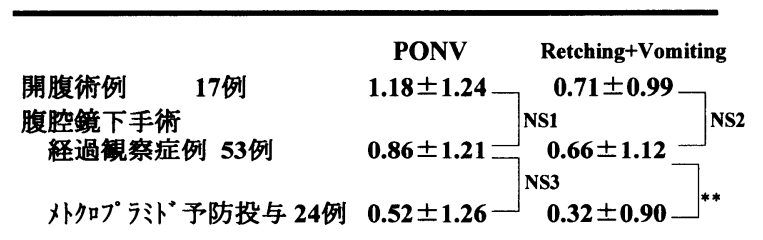

** $p<0.05 \quad$ NS1 $p=0.51 \quad$ NS2 $p=0.88 \quad$ NS3 $p=0.24$

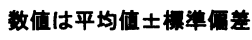

5. 術後 4 時間以降のPONV発現回数（表 6 ）

PONV回数を術後 4 時間以降に限って検討し た。PONVは開腹（子宮全摘出）例では $0.82 \pm$ 0.95 回、腹腔鏡下手術症例で観察群 $0.74 \pm 1.04$ 回、 メトクロプラミド予防的投与例の $0.20 \pm 0.65$ 回に 認められた。そのうち嘔吐 (retchingとvomiting) に限るとそれぞれ $0.53 \pm 0.71$ 回、0.53 00.89 回、 $0.08 \pm 0.28$ 回であった。経過観察例とメトクロプ ラミド予防的投与例とはPONVについては有意に

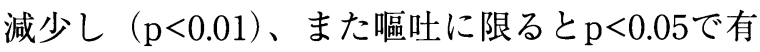
意差に回数を押さえることができた。開腹術と腹 腔鏡下手術（経過観察例）では、PONV頻度 $(\mathrm{p}=0.76)$ および嘔吐（ $\mathrm{p}=0.99 ） に$ 有意差はなか った。この検定は $\mathrm{t}$ 検定をおこなった。

表 6 術後 4 時間以降のPONV発現回数

\begin{tabular}{|c|c|c|}
\hline 開腹術例 ， 17例 & $\begin{array}{c}\text { PONV } \\
0.82+0.95\end{array}$ & $\begin{array}{c}\text { Retching+Vomiting } \\
0.53 \pm 0.71\end{array}$ \\
\hline 用腹俅例 手術 & & NS1 \\
\hline 経過観察症例 53例 & $0.74 \pm 1.04=$ & $0.53 \pm 0.89$ \\
\hline 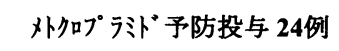 & $0.20 \pm 0.65$ & $\left.{ }^{*} 0.08 \pm 0.28\right]^{* *}$ \\
\hline
\end{tabular}

${ }^{\star} p<0.01 \quad{ }^{* *} p<0.05 \quad$ NS1 $p=0.76 \quad$ NS2 $p=0.99$

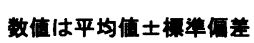

6. 術後 4 時間以降のPONV点数化による評価 (表7）

PONV点数は非予防的投与群としての開腹症例 で平均 2.47 点で、腹腔鏡下手術では、平均 2.06 点 でありメトクロプラミド予防的投与群では平均 0.48 点であった $(\mathrm{p}<0.05)$ 。PONVを点数化して 重み付けをすると有意差が認められた。開腹術と 腹腔鏡下術後経過観察例では有意差はなかった $(\mathrm{p}=0.63)$ 。この検定は $\mathrm{t}$ 検定を利用した。

表 7 術後 4 時間以降のPONV点数化による評価

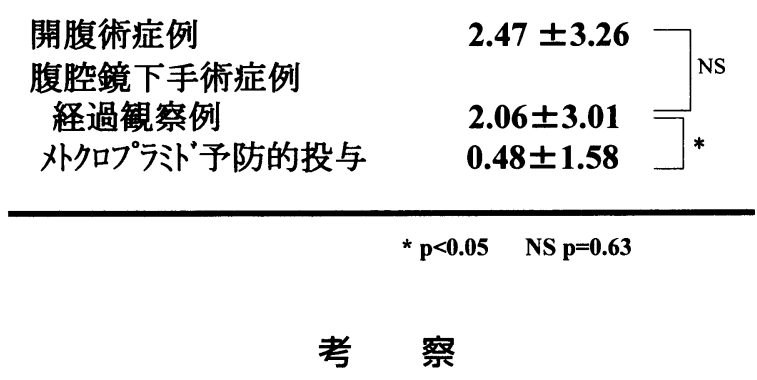

PONVの発現機序は、その発現頻度が、全身麻 酔下の腹部手術に高いことから腹部手術および麻 酔薬等による消化管への刺激セロトニンの遊離を 惹起させ、求心性迷走神経を興奮させること、あ るいは麻酔薬などの孤束核への直接刺激などが PONVの発現の一因と推定されている ${ }^{7.8)}$ 。

婦人科の腹腔鏡下手術でPONVの頻度は低いと いう文献 (外妊手術 $)^{9)}$ や反対に多く発現すると いう報告もある ${ }^{1)}$ が今回の検討では開腹術と腹腔 鏡下手術とにPONVの有意な差はなかった。

術後の悪心嘔吐のリスクについてはいくらかあ げられている。女性であること、肥満、動摇病 の既往、術後のオピオイドの使用、アルコール 飲習慣のないことなどが危険因子との報告があ る $^{10.11)}$ 。女性は男性より $2-4$ 倍頻度が高いとさ れ、ホルモンの影響がいわれている。手術も月経 開始後 8 日以内なら術後の悪心嘔吐の頻度も少な い、すなはち黄体期にPONV頻度が高いとの報告 もある ${ }^{12.13)}$ 。ただ今は、生理周期とPONVの関係 は一定の見解は得られていない. ${ }^{11}$ 。ままた麻酔時 間や手術時間はPONVに影響しない都の報告があ る ${ }^{13)}$ 。笑気を使用したりすると気腹にともなう消 化管の拡張で悪心率が上がる1”。また、プロポフ オールを使用すると術後早期の嘔吐は少ないなど の報告がある ${ }^{11}$ 。

メトクロプラミドは、消化管運動調節作用と抗 ドーパミン作用により制吐作用を表す。ドロペリ ドールは抗ドーパミン作用による制吐剂である。 5-HT3製剤はセロトニン 3 型受容体拮抗薬であり PONVに対して制吐剂投与の術後効果は認められ ている。しかしこれらの効果は嘔吐後に使用し24 時間で嘔吐があった症例はプラセボで60-72\%で、 メトクロプラミドで $35-70 \%{ }^{14)}$ 、ドロペリドール で20-57\% ${ }^{15,16)}$ 、5-HT3拮抗薬で8-52\% ${ }^{14,17)}$ である という。

当科の結果では術後の 5 時間目以降の悪心嘔吐 
することが確認された。PONV治療に関した検討 で今回のような予防的に時間を決めて術後4-5時 間に投与する報告がある ${ }^{18)}$ 。日㷌り手術の多い外 国ではこの嘔吐を rebound vomitingとして術後 4 時間目に嘔吐防止薬を使用することがある。今 回のわれわれの予防的投与検討の方法を支持する 文献である。その文献の結果は、 2 剂併用などで 日㷌り手術で退院後 3 から24時間の嘔吐は減少し たが、 2 倍量のオンダンセトロンやドロペリドー ルを使用しても予防効果は変わらなかったようで ある。

当院の検討では、予防的メトクロプラミド投与 は、術後時間を区切らずに全体を対象とした結果 では、症例別ではPONVおよび煰吐を押さえるこ とができた（ $\mathrm{p}<0.05 ）$ 。また、回数では嘔吐に効 果があった $(\mathrm{p}<0.05)$ 。術後 4 時間以降の検討で は術後のPONVおよび嘔吐の両方に効果があっ た。特にPONVに対しては経過観察群と比較して $\mathrm{P}<0.01$ で有意差があった。嘔吐に関しても $\mathrm{p}<0.05$ で有意差があった。このように術後の制吐剤予防 的投与は投与しないより有意差をもって悪心およ び哣吐回数を減らす効果があることがわかった。 予防的投与方法はこれ以後薬剤や投与量など考慮 し、今後その有用性に以後検討を加えてゆきたい。 ただ、この術後 $4-5$ 時間目の投与によるメトク ロプラミド予防的投与では、術後早期から初期に 起こるPONVは予防できないのであり、それらは 症状に応じて医師の監視下でメトクロプラミドや ドロペリドール等の使用を考慮する必要があろ う。術直後の嘔吐は腹膜伸展による不快感により 起こり ${ }^{5)}$ 、早期に発症する煰吐は約 $50 \%$ に発症し てその嘔吐は防げないとの報告もある゙”。

5-HT3製剤もいわれるほどの腹腔鏡下手術後の 悪心嘔吐を予防できないでいる ${ }^{11}$ 。この防止のた めに現在考えられていることで理想的な術後の悪 心嘔吐予防法方法といえば、プロポフォール麻酔 は術後の早期の嘔吐発現が低い" ${ }^{1)}$ ので導入し予防 的投与として制吐剤を麻酔導入前に使用し、手術 は短時間で終了し、術後も制吐剤を 4 時間目あた りに使用し、 acupressure ${ }^{19)}$ も利用すればかなり 防げるのではないかと思われる。また1999年の東 邦大学の本学会の発表 ${ }^{201}$ のPatient-controlled Antiemesis使用も十分考慮することが必要であ ろう。動摇病の既往（乗り物酔い）などのあるこ とを術前に聞いておくことが大切であり、この既 往の患者には特にPONVに気をつける必要があ る。
今後は、制吐剤 2 郕併用療法やacupressure療 法も検討に加えてゆきたい。

この論文要旨は、第40回日本産科婦人科内視鏡 学会（東京、2000年 8 月）にて発表した。

\section{文 献}

1) Watcha M.F. et al: Postoperative nausea and vomiting, it's etiology, treatment and prevention. Anesthesiology, 77:162,1992.

2) Kenny G.N.C. : Risk factor for postoperative nausea and vomiting, Anaesthesia,49:6,1994.

3 ) Jakobson J. et al : Nausea and vomiting after laparoscopic gynecological surgery: a study of the incidence and the effects of tropistron prophylaxis,

J Laparoendosc. Adv Surg Tech A , 9(1): 51,1999.

4 ) Borgreat A et al :Gynecologic laparoscopic surgery is not associated with an increase of serotonin metabolites excretion. Anesth Analg , 87(5):1104,1998.

5 ) 飯富貴之、鳥海信一、近藤明男 他：腹腔鏡下胆 襄摘出術の術後嘔気・嘔吐に及ほす影響。

麻酔, 44(12):1627,1995.

6 ）横田浩史、天羽敬鿆、並木昭義 他：

塩酸オンダンセトロン注射液の予防的単回投与に よる術後悪心嘔吐に対する臨床効果.

新薬と臨床、147(4):524,1998.

7 ) Palazzo M.G.A et al:Anesthesia and emesis I Can J Anaesth ,31:1978,1984

8 ) Bunce K.T. et al: The role of 5-HT in postoperative nausea and vomiting. Br. J Anaesthesia, 69(supple.1):60s, 1992

9 ) 亀井俊哉、津隈崇志、寺田享志 他 : 婦人科ラパロスコピーによる子宮外妊娠手術では 術後の悪心嘔吐の頻度は減少する.

日本臨床麻酔学会誌、18(8):S329,1998.

10) Koivuranta M, et al: A survey of postoperative nausea and vomiting. Anaesthesia, 52:443.1997.

11）横田浩史：術後の悪心嘔吐 日本臨床麻酔学会誌、17(8):S113,1997.

12) Beattie WS et al:Menstration increases the risk of nausea and vomiting after laparoscopy Anesthesiology 78:272.1993.

13) Leamann J:Surgical and patient factors involved in postopertive nausea and vomiting

Br. J Anaesth , 89( suppl 1):24S,1992

14) Naguib M,et al: Prophylactic antiemetic therapy with ondansetron, tropisetron, granisetron and metoclopramide in patients undergoing laparoscopic cholecystectomy:a randamized, double- 
blind comparison with placebo

Can. J Anaesth , 43:226,1995.

15) Spliter W.M. et al: Ondansetron is a better prophylactic antiemetic than droperidol for tonsillectomy in children.

Can. J Anaesth, 42:848,1995.

16) Tang J. et al: A comparison of costs and efficacy of ondansetron and droperidol as prohpylactic antiemetic therapy elective out-patient gynecologic procedures

Anaesth Analg, 83:304,1996.

17) Davis PJ et al: Effects of antiemetic therapy on recovery and hospital discharge time. A doubleblind assessment of ondansetron, droperidol, and placebo in pediatric patients undergoing amburatory surgery.

Anaesthesiology 83:956.1995.

18) Warrick PD, et al: Treating "rebound" emesis following outpatient gynecologic laparoscopy:the efficacy

of a two-dose regimen of droperidol and ondansetron.

J Clin Anesth , 11(2):119,1999.

19）川内泰子、林田道子、竹内雅依 他：婦人科術後の 悪心嘔吐に対するAcupressureの効果

臨床麻酔、24(1):21,2000.

20）内出一郎、森田峰人、中熊正仁 他：腹腔鏡下術後 の悪心嘔吐へのPatient-controlled Antiemesis 使 用に関する検討.日産婦内視鏡学会誌15(1):186,1999. 